\title{
Transport's digital age transition
}

\author{
Glenn Lyons \\ University of the West of England, Bristol \\ Glenn.Lyons@uwe.ac.uk
}

\begin{abstract}
World Wide Web. We have seen some remarkable developments as part of the digital age revolution in the last quarter of a century. These have taken place concurrently with a motor age that is possibly past its prime. A number of major motor manufacturers have faced disappointing sales or financial crisis alongside several countries seeing a halt to the historic trend of growing car use. The co-existence of the motor age and the digital age prompts this paper to consider the hypothesis that society is undergoing a fundamental transition from a regime of automobility to something significantly different. The paper considers what has characterized the motor age and proceeds to examine the digital revolution and how this is changing people's opportunity to access people, goods services and opportunities. The range of interactions between the motor age and the digital age are addressed, underlining the difficulty in establishing the net consequence of one for the other. The new debates concerning 'peak car' are considered in which the digital age is identified as potentially one key factor responsible for observed changes in car use. The paper then focuses upon a socio-technical conceptualization of society known as the Multi-Layer Perspective to examine its hypothesis. The hypothesis remains neither supported nor not supported. Transport's future in the digital age is uncertain and the paper sets out some views on resulting policy considerations and research needs.
\end{abstract}

\section{Article history:}

Received: March 30, 2014

Received in revised form: July 17, 2014

Accepted: July 19, 2014

Available online: October 27, 2014

Keywords: Motor age, digital age, ICTs, regime change, peak car, travel demand

\section{$1 \quad$ Introduction}

This paper contends that a fundamental transition is occurring in those societies which have hitherto embraced and centralized the motor car and which are now (also) embracing the digital age. It suggests that we are some years into a process of gradual yet significant change away from the car as a foreground innovation in human connectivity with its important symbolic as well as functional meaning.

This change is taking us into a recast form of society brought about by the affordances of the digital age revolution in which the car is set to become a background, functionally supporting technology. It will be accompanied and overshadowed by a much greater richness in forms of being able to reach people, goods, services and opportunities made possible by information and communications technologies

Copyright 2014 Glenn Lyons

http://dx.doi.org/10.5198/jtlu.2014.751

ISSN: 1938-7849 | Licensed under the Creative Commons Attribution - Noncommercial License 3.0

The Journal of Transport and Land Use is the official journal of the World Society for Transport and Land Use (WSTLUR) and is published and sponsored by the University of Minnesota Center for Transportation Studies. This paper is also published with sponsorship from WSTLUR and the Institutes of Transportation Studies at the University of California, Davis, and the University of California, Berkeley. 
(ICTs). Car dependence will abate as the spatial and temporal configurations of social and economic participation in society become more flexible. This will have major implications for our transport and land use systems.

The paper draws together for the first time a number of different territories of examining change in order to build its case for fundamental transition occurring. The paper is a polemic and thus constitutes a contestable, even if plausible, proposition. It therefore also underlines a level of uncertainty, unprecedented in recent times, over the future of demand for travel. In the face of such uncertainty, there is a need for transport policymakers to move away from their predisposition of forecasting the future and responding to it. They should instead be persuaded of a virtue of uncertainty - namely an entitlement, if not imperative, to make choices intended to shape the future-both of transport and society.

At the outset of the paper, it is important to stress the nature of change in society. Sometimes large scale changes are dramatic, brought about by the overthrow of a political regime, a natural disaster, an energy shock and so on. However, more commonly change in society arises from an accumulation of modest adaptations over time which individually may be imperceptible and yet which become cumulatively significant. It is only by looking back over time that we come to appreciate the significance of the change that has occurred. As individuals and thus as a society overall we evolve in tandem with, and as part of, the changes taking place. In this context, change can be "stealthy" as well as profound. As individuals we age. This is not something we notice day to day but it is with certainty that we grow older and only by reflecting on our youth do we then wonder where the time went and how the face in the mirror could be so different. The same can be said of our transport and land use systems. A bit more capacity here, a few more cars there, a new development approved, further parking needed, another set of traffic lights, a bit more time spent in congestion - all accumulating to transform our built environments and our behaviours. Change is a process, not an event; and in the context of this paper is a process that spans decades.

The paper has, as its storyline, the following. From its early and faltering beginnings, the motor age came to define the very fabric of society (section 2). It provided an apparently liberating force not only for the few but for the many as a means to reach destinations in order to participate in economic and social activity. We are so conditioned by our existence in a car-based society that it has been difficult to conceive of things being fundamentally different. However, from its own early and faltering beginnings has come the growing force for change of the digital age (section 3). We have been provided with different ways of undertaking activities in time and space as computer screens have come alongside our windscreens. As the motor age and digital age now exist concurrently, the unanswered question is whether the latter is fundamentally disrupting the former. There has tended to be a "bottom-up" attempt to answer this question by looking at the different ways specific ICT-enabled behaviors have affected travel (section 4). What is unresolved, and perhaps insoluble, is how the many different behaviors and effects combine overall. The aggregate picture appears to have been one of traffic (and congestion) continuing to grow in the face of an advancing digital age. However, it has emerged that in the early years of the new millennium car travel (especially per capita) has seen, in a number of countries, an interruption to its long-run trend of growth (section 5). This could suggest that the motor age is starting to see some destabilizing effects that may be (indirectly) attributable to the digital age. Something more profound may be happening than has been hitherto revealed or substantiated by the bottom-up approach referred to above. By bringing the elements of the storyline together, the hypothesis can then be articulated that we are in the midst of a regime transition that is seeing the motor age becoming overshadowed by the digital age (section 6). As the transition proceeds, the new affordances of how, where and when we can connect with people, goods, services and opportunities will increasingly shape our social practices, land use patterns, our build environment and transport systems. This presents new challenges and opportunities for transport policymakers (section 7).

While in some parts the paper draws upon insights from the UK, its thesis is applicable to many if not all developed economies and countries that have embraced the motor car and which are now em- 
bracing ICTs and the social and business practices they afford. Just as different countries transitioned into the motor age at different times and rates, so too is the hypothesized transition likely to vary internationally.

Alongside the theme of change, the other binding theme within the paper is that of access or accessibility. Drawing upon SEU (2003), accessibility concerns people being able to reach other people, goods, services and opportunities "at reasonable cost, in reasonable time and with reasonable ease" (SEU, 2003, 1). It is about the connectivity that brings about social and economic participation in society.

\section{The motor age}

There are considerable writings that capture the history of how the motor car came to fundamentally shape our towns, cities and ways of life (e.g., Kulash 1996; Davison 2004; Norton 2011; Dudley 2014). We are all, to greater or lesser extents, children of the motor age which stretches back for a century. Societies in many countries have only ever known an existence in a world where the car was king-and yet even the early beginnings of the motor age were showing signs of its problematic symptoms (Figure 1).

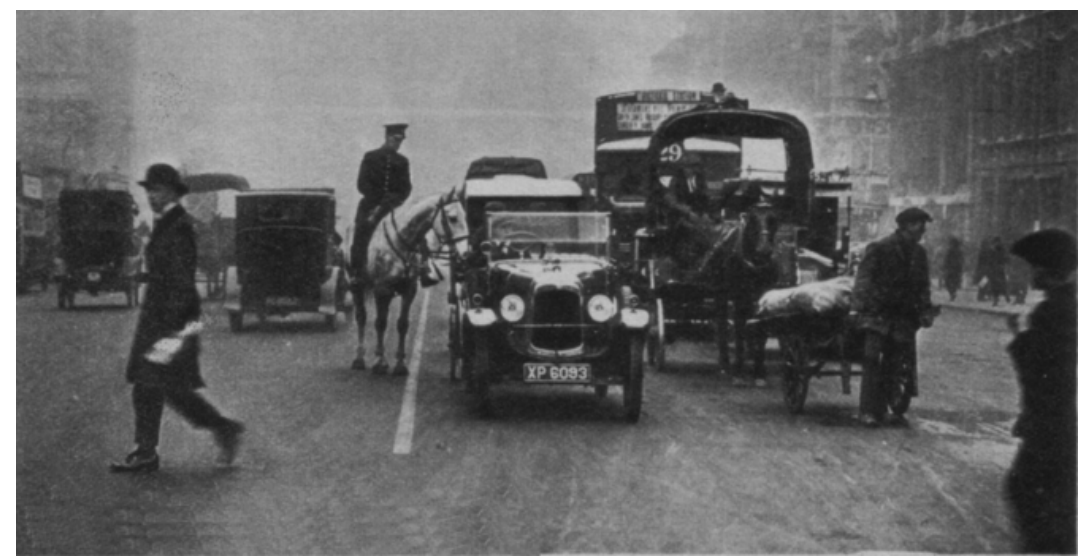

Figure 1: 1924 image from Morton (1934). This is the first white line to be laid down in a London street as an experiment in solving the traffic congestion problem, which at this time had become acute.

The motor car arrived into a world which had, as one of its characteristics, the primacy of physical location. Activities took place in specific places. Where you were was a strong signal of what you were doing. Fundamentally, the motor car was a means of transcending distance to reach activity locations and one that could do so at greater speed than its horse-drawn predecessors. It enabled an individual a potent element of independence in terms of locations they could reach and the times they chose to do so. Such independence and the accessibility it afforded had great prospect for opportunity in economic and social terms. The liberating force of the motor car and its ensuing mass production began to make freedom and independence available to the many, not just the few. However, the opportunities for motor car owners were dictated in part by the infrastructure available for their vehicles to use. Society responded by expanding that infrastructure and allowing it to permeate and dominate the landscapes of our towns and cities in pursuit of the prosperity that such mass mobility was providing. More and more people sought to take advantage of this age of the motor car and vehicles were cherished as prized possessions that embodied status and projected image. Transcending distance meant in turn that land use changes responded to the affordances of the motor car. Urban sprawl developed as attractive and affordable household locations were sought and new business models were developed such as out-of-town superstores for shopping. 


\subsection{From independence to dependence}

A society was created over time that saw the original notions of independence turn into dependence (Goodwin 1995) — the car for many was no longer a luxury but a necessity for economic and social engagement in society. People were then faced with tolerating the abundance of car ownership and car use in the form of parked cars dominating our streets and urban centers and moving cars struggling to make progress on over-crowded highways. The challenges of accommodating the motor car in our towns and cities were well recognized in the 1960s (Buchanan 1963). A move from desire to necessity has prompted notions in more recent years that our love affair with the car may be over.

The motor age's centrality for society, love affair or not, has been underlined by an important association-the apparent coupling between economic growth and passenger transport growth. We needed to keep the traffic moving to prosper, or so it seemed (see Figure 2-the subsequent picture for the mid1990s onwards is returned to in section 6). The following UK example of changing policy position suggests that there is a deeply held belief institutionally that the dominance of the car is here to stay. Freedom to drive has stood the test of time largely unscathed as an apparent human right. Policymakers must tread with care if they wish to challenge that freedom; and they fear the destabilizing effect for the economy of steps to curb rather than support car traffic.

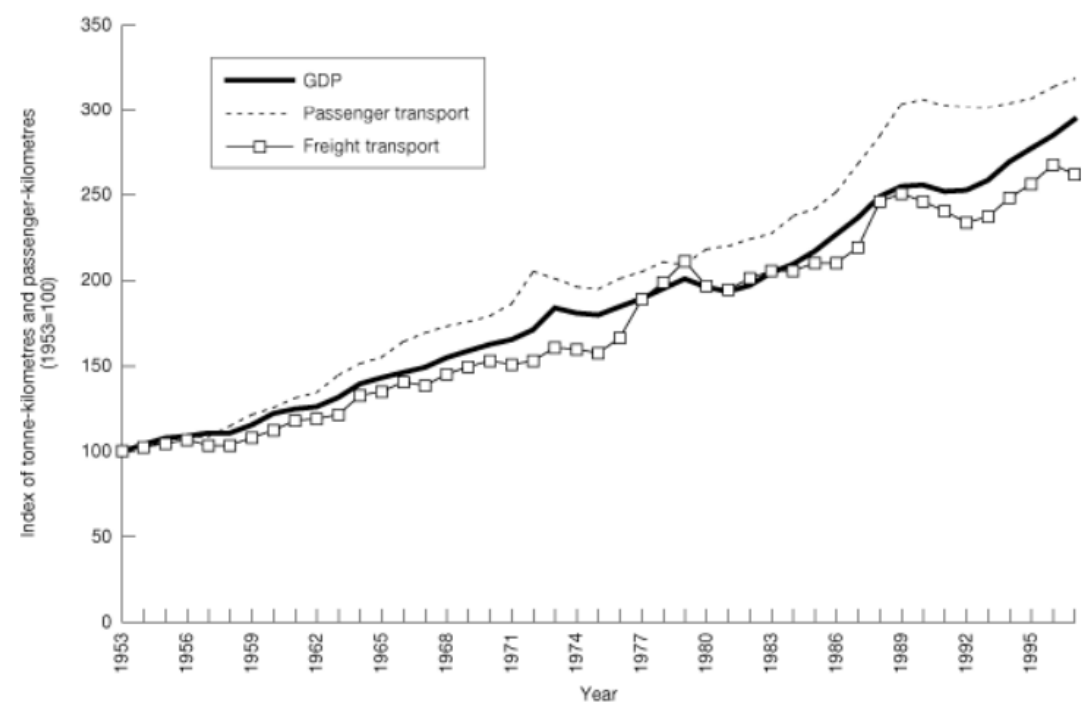

Figure 2: UK trends in transport activity and economic activity (Image taken from SACTRA $(1999,24)$ )

The prospect that it was possible to build our way out of congestion and thereby continue to fuel economic prosperity has been compelling. The motor age in the UK perhaps saw its last great policy stand in this regard in 1989 when Margaret Thatcher's Conservative Government published its Roads to Prosperity White Paper (DoT 1989) which was dubbed Britain's biggest road building program since the Romans. However, the program never happened. Evidence was mounting that aside from the challenges of affordability, 'predict and provide' was not the answer. A major report to the UK Government in 1994 (SACTRA 1994) concluded new road capacity not only changed the patterns of traffic but could generate some new traffic suggesting that road building could not keep pace with traffic growth. The next White Paper from a new Labour Government marked an apparent watershed for the motor age in 1998 in stating that "since new roads can lead to more traffic, adding to the problem not reducing it, all plausible options need to be considered before a new road is built" (DETR 1998, 57). The UK has 
subsequently faced an era in which it has sought to "sweat the asset" in terms of its transport system: new technologies under the banner of "intelligent transport systems" have been turned to for improvements to traffic management; and demand management has been given serious attention in order to encourage use of alternatives to the car.

However, the UK most recently, as it struggles to emerge from recession under a Conservative-led coalition Government, has begun embracing "innovations" such as active traffic management which involves opening up the hard shoulder of motorways to running traffic at times of congestion (in effect providing more capacity). The Government's latest road traffic forecasts show, for the "central projection," a 43\% growth in road traffic by 2040 allied to projected population growth and economic activity (DfT 2013). In its National Infrastructure Plan (HM Treasury 2013), the Government signals an apparent resurrection of predict and provide thinking allied to a continued assumption of the primacy of the coupling between and economic activity and vehicular traffic. It sets out commitment to tackle congestion and support economic growth by a level of investment in roads unmatched since the 1970s.

One might say that "old habits die hard." As Dudley (2014) highlights, society has, for some time now, faced a "triple interlocking" effect of the motor industry, public use of its products and infrastructure provision to support use. This continues to create strong forces for preserving car dependence, concurrently with inertia in relation to any prospects for fundamental change.

The debates of the motor age have become more complex as decarbonizing the transport system has joined decongesting the transport system as an economic imperative; and as public health has been increasingly recognized for its links with our forms of mobility. Nevertheless, there has seemed little to shake the foundations of the motor age. We are given the promise that technology can tackle transport's climate change credentials (HM Treasury, 2008) as well as automate our cars to improve safety and efficiency. Far from being past its prime, the motor age-it would seem to some-is evolving.

However, it has now been accompanied by the digital age, which undoubtedly constitutes a significant new force of change in society-with potentially very important implications for transport.

\section{The digital age}

It is a challenging business contemplating the capabilities and consequences of an unfolding new age. Two popularized/paraphrased quotes that have become notable for being overtaken by events are as follows: "I think there is a world market for maybe five computers" (Thomas Watson, chairman of IBM 1943); and "computers in the future may weigh no more than 1.5 tons" (Popular Mechanics, forecasting the relentless march of science 1949). There continue to be underestimations of how far ICTs may advance. For example, in the early 1990s Hepworth and Ducatel (1992) could see no prospects for an evolution of online grocery shopping alongside in-store shopping based on the assessment at that time of technological possibility. Yet two decades on, online accounts for some $4 \%$ of grocery sales in the UK with online sales estimated at $£ 4.8$ billion in 2010, up over 900\% since 2000 (Lyons 2002; IGD 2011).

\subsection{The digital revolution}

Personal experience matters in shaping our perspectives as researchers and commentators. My 1980s teen years included the arrival of early home computing - principally as an opportunity to play games and to write one's own software to play games. My first computer, the Sinclair ZX81 (the UK's first mass market home computer), had 1000 bytes of memory - a far cry from the gigabytes and even terabytes $\left(10^{12}\right.$ bytes) our home computers deal in today; and no notion of electronically networking with others. Leaping forward, 2014 marks the $25^{\text {th }}$ birthday of the World Wide Web. To refer to my own childhood experience is to note in turn how 'stealthy' change has accumulated in a dramatic fashion. Table 1 is a compilation of year-by-year developments over 17 years within the digital revolution starting with the 
arrival of Google. This was 1997, the same year that Steven Levy (senior writer for emerging technologies magazine Wired) stated that "the world is poised on the cusp of an economic and cultural shift as dramatic as that of the Industrial Revolution" ("Random Access", Newsweek, 17 July 1997).

Such a compilation provides a stark reminder of how many elements of the digital revolution have penetrated and will penetrate the lives of many people across the world ${ }^{1}$ and yet elements which we have absorbed and perhaps taken for granted or become dependent upon. Pause and really try to recall a pre1997 world where to Google, Skype, eBay, Facebook and Tweet were not known verbs. It is not necessarily that easy to do-even less so for those now reaching university age. We have moved into a world where we can search for and engage with almost anything online, whether information, other people, goods or services; and we can do so (if equipped) from (almost) anywhere and anytime-whether at our desks, on the move or in our living rooms. Many people live now in an "always on" world. We have moved from pens to keyboards; from keyboards to swiping fingers across screens; and are now at the point of voice-responsive headsets to interact with the digital world. An important question is how much more innovation and innovation diffusion (Rogers, 1962) is still to come? Are we reaching the limits of what a digitally connected world has to offer or does Table 1 merely reflect the early beginnings?

\footnotetext{
${ }^{1}$ It is estimated (http://www.internetworldstats.com/stats.htm) that over 2.4 billion people (over a third of the world's population) are now connected to the Internet. While this leaves the majority of people still not connected the same is not true in North America with $79 \%$ of its population connected and a figure of $63 \%$ for Europe. From 2000-2012 there has been a growth in overall Internet users of over $560 \%$.
} 
Table 1: Chronology of digital age revolution developments

\begin{tabular}{|c|c|c|}
\hline Year & Digital revolution development & Present day observation \\
\hline 1997 & $\begin{array}{l}\text { Search engine Google.com registered as domain } \\
\text { name and personal information manager } M i \text { - } \\
\text { crosoft Outlook first made available as part of } \\
\text { Microsoft Office }^{a^{2}}\end{array}$ & $\begin{array}{l}\text { Google now processes over } 1 \text { billion search requests every } \\
\text { day; by } 2010 \text { it was estimated that the average } \\
\text { knowledge worker received nearly } 100 \text { emails per day }{ }^{a}\end{array}$ \\
\hline 1998 & $\begin{array}{l}\text { The first commercially available MP3 personal } \\
\text { music player MPMan F1O was launched }\end{array}$ & $\begin{array}{l}\text { The Apple iPod (launched in 2001) has since become } \\
\text { the best known brand of MP3 player with worldwide } \\
\text { sales of } 350 \text { million by September } 2012^{\mathrm{a}}\end{array}$ \\
\hline 1999 & Peer-to-peer selling site $e$ Bay launched in $\mathrm{UK}^{\mathrm{a}}$ & $\begin{array}{l}\text { Now has } 14 \text { million active users (around one fifth of the } \\
\text { UK population) }{ }^{c}\end{array}$ \\
\hline 2000 & $\begin{array}{l}\text { The Nasdaq index of leading technology shares } \\
\text { peaked before rapid decline - marked as the } \\
\text { bursting of the Dot Com bubble }\end{array}$ & $\begin{array}{l}\text { In } 2013 \text { the Nasdaq topped } 4000 \text { for the first time in } 13 \\
\text { years - still } 20 \% \text { below its } 2000 \text { peak }^{\text {e }}\end{array}$ \\
\hline 2001 & $\begin{array}{l}\text { Collaboratively edited encyclopedia Wikipedia } \\
\text { formally launched }^{a}\end{array}$ & Now has over 30 million articles across 287 languages $^{a}$ \\
\hline 2002 & $\begin{array}{l}\text { Online peer-to-peer music sharing service } \\
\text { Napster declared bankrupt }{ }^{\mathrm{a}}\end{array}$ & $\begin{array}{l}\text { Napster and later services credited for the demise of the } \\
\text { 'album era' in popular music - } 2012 \text { saw digital down- } \\
\text { load sales of music in the UK exceed sales on CD and } \\
\text { record for the first time }\end{array}$ \\
\hline 2003 & $\begin{array}{l}\text { Voice and video over Internet (free to use) call- } \\
\text { ing service Skype founded }\end{array}$ & $\begin{array}{l}663 \text { million registered users at the end of } 2010^{\mathrm{a}} \text { and } \\
\text { "Skype's on-net (Skype to Skype) international traffic grew } \\
36 \text { percent in 2013, to } 214 \text { billion minutes" }\end{array}$ \\
\hline 2004 & $\begin{array}{l}\text { Official launch of the UK Government's door- } \\
\text { to-door journey planner Transport Direct }\end{array}$ & $\begin{array}{l}\text { By } 2012 \text { the service had handled over } 110 \text { million user } \\
\text { sessions }{ }^{\mathrm{h}}\end{array}$ \\
\hline 2005 & Video sharing site YouTube launched ${ }^{a}$ & $\begin{array}{l}\text { Now has more than } 800 \text { million unique users a month } \\
\text { and "[i]t is estimated that in } 2007 \text { YouTube consumed as } \\
\text { much bandwidth as the entire Internet in 2000"a }\end{array}$ \\
\hline 2006 & $\begin{array}{l}\text { Social networking site Facebook open to everyone } \\
\text { aged } 13 \text { and over and microblogging service } \\
\text { Twitter launched }\end{array}$ & $\begin{array}{l}\text { Facebook now has more than one billion active users and } \\
\text { Twitter, by the end of 2012, had } 200 \text { million monthly } \\
\text { active users }^{a}\end{array}$ \\
\hline 2007 & Apple's first iPhone smartphone went on sale & By 2012 over 250 million units sold ${ }^{a}$ \\
\hline 2008 & $\begin{array}{l}\text { Online shop Apple App Store launched - selling } \\
3^{\text {rd }} \text { party applications for the iPhone }\end{array}$ & $\begin{array}{l}\text { By } 2013 \text {, over } 800,000 \text { apps available with over } 40 \text { bil- } \\
\text { lion app downloads }{ }^{\mathrm{a}}\end{array}$ \\
\hline 2009 & $\begin{array}{l}\text { International version of e-book reader Amazon } \\
\text { Kindle launched }{ }^{a}\end{array}$ & $\begin{array}{l}\text { Worldwide ebook sales set to outstrip their print equiva- } \\
\text { lents in } 2014 \text { - but with year on year ebook sales having } \\
\text { fallen for the first time }\end{array}$ \\
\hline 2010 & Apple's iPad tablet computer launched ${ }^{a}$ & By October 2013170 million units sold ${ }^{j}$ \\
\hline 2011 & $\begin{array}{l}\text { Apple's financial reserves briefly larger than those } \\
\text { of the US government }{ }^{\mathrm{a}}\end{array}$ & $\begin{array}{l}\text { In } 2012 \text { Apple was confirmed as the most valuable } \\
\text { company of all time }\end{array}$ \\
\hline 2012 & $\begin{array}{l}\text { Fourth generation }(4 G) \text { of mobile telecommuni- } \\
\text { cations technology launched in } 11 \text { UK cities }\end{array}$ & $\begin{array}{l}\text { "[E]xtra speed and capacity allows for high-quality stream- } \\
\text { ing of audio, video and other content while on the move" }\end{array}$ \\
\hline 2013 & $\begin{array}{l}\text { Wearable computer Google Glass with optical } \\
\text { head-mounted display made available to testers } \\
\text { and developers }\end{array}$ & Consumer launch set for later in $2014^{\mathrm{m}}$ \\
\hline \multicolumn{3}{|c|}{$\begin{array}{l}\text { Information sourced (as at 17/07/2014) from: } \\
\text { ahttp://en.wikipedia.org/ } \\
\text { b http://www.theregister.co.uk/2008/03/10/ft_first_mp3_player/ } \\
\text { chttp://pages.ebay.co.uk/aboutebay/thecompany/companyoverview.html } \\
\text { d http://news.bbc.co.uk/2/hi/business/8558257.stm } \\
\end{array}$} \\
\hline
\end{tabular}




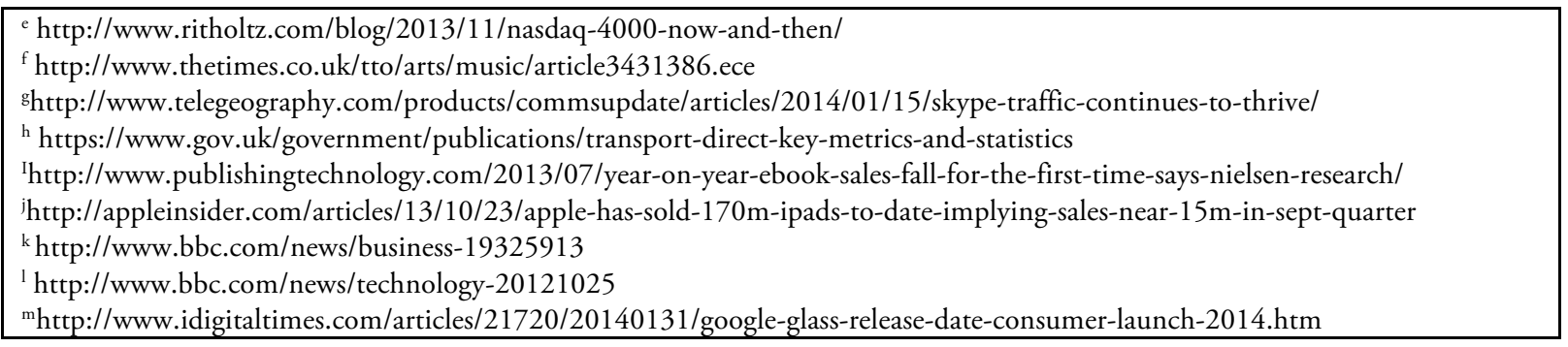

\subsection{New affordances of access}

Another key question is whether the developments in Table 1 have been incidental to, or instrumental in, shaping changes in social and business practices over the 17-year period? The Table gives a strong sense that digital age advances are penetrating people's lives - but how is this affecting people's participation in society? To what extent are we accessing (reaching) people, goods, services and information online? For Great Britain ${ }^{2}$, the Office for National Statistics is tracking Internet use over time. Changes from 2007 to 2013 in the proportions of adults (aged 16+) engaging in online activities are shown in Table 2. This highlights the substantial (ongoing) growth in the use of the Internet for access. It also highlights that levels of online activity engagement vary across different elements of the adult population. Alongside the information shown in the Table, the same source (ONS 2013) reveals 1 in 5 people have bought food or groceries over the Internet and $43 \%$ have bought household goods. $72 \%$ of people in 2013 reported having made some sort of purchase over the Internet, up from 53\% in $2008.53 \%$ of people had accessed the Internet using a mobile phone in 2013 compared to $24 \%$ in 2010.

\footnotetext{
${ }^{2}$ Great Britain (GB) is made up of England, Wales, and Scotland. The United Kingdom (UK) is made up of Great Britain and Northern Ireland.
} 
Table 2: Percentage of people aged 16+ engaged in different online activities (including age band for which the highest proportion for 2013 is identified) (ONS, 2013)

\begin{tabular}{|c|c|c|c|}
\hline Internet activity & 2007 & 2013 & $\begin{array}{l}2013 \text { high } \\
\text { (age group) }\end{array}$ \\
\hline Sending/receiving emails & 57 & 75 & $89(25-34)$ \\
\hline Finding information about goods and services & 58 & 66 & $77(25-44)$ \\
\hline Reading or downloading online news, newspapers or magazines & 20 & 55 & $72(25-34)$ \\
\hline Social networking, e.g., Facebook or Twitter & - & 53 & $93(16-24)$ \\
\hline Using services related to travel or travel related accommodation & 42 & 50 & $65(25-34)$ \\
\hline Internet banking & 30 & 50 & $76(25-34)$ \\
\hline Seeking health related information & 18 & 43 & $59(25-34)$ \\
\hline Consulting wikis & - & 43 & $60(16-24)$ \\
\hline Looking for information about education, training or course offers & 25 & 31 & $62(16-24)$ \\
\hline Downloading software (other than games software) & 16 & 31 & $55(16-24)$ \\
\hline Selling goods or services over the Internet & 12 & 28 & $45(25-34)$ \\
\hline Telephoning or making video calls over the Internet via a webcam & 8 & 25 & $40(16-24)$ \\
\hline Looking for a job or sending a job application & 14 & 24 & $45(16-24)$ \\
\hline Participating in professional networks & - & 15 & $23(25-44)$ \\
\hline Posting opinions on civic or political issues & - & 10 & $15(25-34)$ \\
\hline Doing an online course & 4 & 9 & $18(16-24)$ \\
\hline Taking part in online consultations or voting on civic or political issues & - & 7 & $10(35-44)$ \\
\hline
\end{tabular}

Homeworking has been a practice long associated with the possibilities of the digital revolution with the prospect that it might replace the daily commute and reduce peak-period congestion. For some, tracking its fortunes over time is a test of whether the digital age really is making an impact on the motor age. However, tracking is beset with differences of, and ambiguities associated with, definition across studies. The UK Labour Force Survey has included questions regarding homeworking on an annual basis which, since 1997, have captured finer details of definition. Felstead (2012) provides the most complete examination of available data over time and change from 1997 to 2010 is shown in Table 3. In terms of absolute numbers, homeworking remains a minority practice. However, its rapidly growing association with the digital age is apparent and the flexible use of the home as one of a number of places of work is increasing. In overview it might be suggested that stealthy but cumulative change is indeed occurring. 
Table 3: Change in homeworking in the UK from 1997 to 2010 amongst people in paid employment (figures reproduced from Felstead (2012) and based on Labour Force Survey data) - percentages relate to total labour force

\begin{tabular}{|c|c|c|c|}
\hline Working practice & 1997 & 2010 & $\begin{array}{l}\% \text { increase } \\
\text { in proportion } \\
\text { of workforce }\end{array}$ \\
\hline Working mainly "In Own Home" & $611,835(2.4 \%)$ & $819,525(2.9 \%)$ & 21 \\
\hline $\begin{array}{l}\text { Working mainly "In Different Places Using Home } \\
\text { as Base" }\end{array}$ & $1,552,859(6.2 \%)$ & $2,394,552(8.4 \%)$ & 35 \\
\hline $\begin{array}{l}\text { Working at least one full day a week at or from } \\
\text { home }\end{array}$ & $2,986,725(11.3 \%)$ & $4,384,360(15.3 \%)$ & 35 \\
\hline $\begin{array}{l}\text { Impossible to carry out work at or from home for at } \\
\text { least } 1 \text { day a week without the use of a telephone } \\
\text { and computer }\end{array}$ & $987,608(3.7 \%)$ & $2,573,822(9.0 \%)$ & 143 \\
\hline $\begin{array}{l}\text { Percentage whose part use of the home is depend- } \\
\text { ent on ICT }\end{array}$ & 33.1 & 58.7 & - \\
\hline
\end{tabular}

\subsection{Generational differences}

Most established commentators within the territories covered by this paper would now be termed a "digital immigrant" - defined by Google 3 as "a person born or brought up before the widespread use of digital technology." While increasing longevity may see digital immigrants remain a substantial proportion of the population for some time, the future will belong to the digital natives—-defined as "[persons] born or brought up during the age of digital technology and so familiar with computers and the Internet from an early age." The footnote to the latter Google definition observes "the digital tools that are reshaping our economy make more sense to young digital natives than to members of older generations." Ten years ago Prensky $(2004,2)$ observed of digital natives that "their online life is a whole lot bigger than just the Internet. This online life has become an entire strategy for how to live, survive and thrive in the 21 st century, where cyberspace is a part of everyday life" (see also Prensky 2001). As noted earlier in this section, lived experience matters. In any look to the future we should ensure "expert" insight from digital immigrants is coupled with 'lived experience' insight from digital natives. As Table 2 highlights, those who are, or are nearest in age to, digital natives are most commonly embracing the digital age in terms of the accessibility to a variety of activities that it provides. Perhaps more than coincidentally, digital natives are those also now associated with declining driving license acquisition and car use (see section 5).

\section{$4 \quad$ Interactions between the motor age and digital age}

The paper has thus far set out a portrayal of the motor age and its profound imprint on society and has in turn sought to depict the dramatic rise of the digital age. A fundamental common denominator between the technologies of the motor age and the digital age is that of access-being able to transcend distance to reach people, goods, services and opportunities: the key to economic activity and social participation in society. One might have been forgiven for assuming that transport policymakers would thus

\footnotetext{
${ }^{3}$ Definition returned from "digital immigrant definition" Google search
} 
take a keen interest in what the digital age had to offer. Yet interest seems to have been limited at best. For example, in 2000 the UK Government encouragingly acknowledged in its Ten Year Plan for transport (DETR 2000) that "the likely effects of increasing Internet use on transport and work patterns are still uncertain, but potentially profound, and will need to be monitored closely." Yet regrettably, there has been little subsequent evidence in the 14 years since of such monitoring-at least by UK transport policymakers. Nevertheless, the appetite in academic research to better understand how the motor age and digital age are interacting has been significant over a long period.

A number of interactions have been identified with the early work of Pat Mokhtarian and Ilan Salomon pioneering expositions of such interactions (Salomon 1986; Mokhtarian 1990). The different key interactions are set out below:

1. Use of ICTs can substitute for travel —an activity is undertaken without the individual needing to make a trip (e.g., teleworking-Andreev et al. (2010)).

2. Use of ICTs can stimulate travel—information flows encourage the identification of activities and encounters at remote locations that individuals then choose to travel to (this can sometimes be a second order effect of substitution-for example teleconferencing widening social contacts which leads to motivations to meet in person (Button and Maggi 1994)).

3. Use of ICTs can supplement travel-increasing levels of access and social participation are experienced without increasing levels of travel (i.e., telecommunications can substitute for an increase in travel (Kenyon et al. 2002; Kenyon et al. 2003)).

4. Use of ICTs can redistribute travel - even if the amount of travel (measured in vehicle or passenger miles travelled) does not change at the level of the individual or at the aggregate, when and between which locations travel takes place can be changed (with implications for levels of traffic flow and thus congestion (e.g., Lyons and Haddad (2008) in relation to part-day homeworking having the potential to displace in time when the daily commute to or from work takes place).

5. Use of ICTs can improve the efficiency of travel—data and information flows can enhance the operation and use of the transport system (commonly considered under the heading of 'intelligent transport systems').

6. Use of ICTs can enrich travel—whereby opportunities to make worthwhile use of time while travelling (multitasking — see Kenyon and Lyons (2007)) are enhanced, helping generate a "positive utility" (Mokhtarian and Salomon 2001; Lyons and Urry 2005).

7. Use of ICTs can indirectly affect travel - technologies can enable or encourage changes to social practices and locational decisions over time that in turn influence the nature and extent of travel (e.g., Hubers and Lyons 2013).

\subsection{Establishing the net effect on travel}

There is a rich and growing body of literature that seeks to explore and understand these different interactions-what was referred to in the paper's introduction as a 'bottom-up' approach. From the motor age perspective, the great unknown is what the net consequence is of the interplay of so many interactions across different people, locations, activities, times and scales. This problem is compounded by the ever changing nature of the digital age technologies and services. Mokhtarian has comprehensively examined the myriad of interactions (Mokhtarian 2003; 2009) spanning both conceptual and empirical insights. She has set out her view (Mokhtarian 2003, 46) that "telecommunications is increasing in share with respect to the other modes [of communication- i.e., travel] but use of all modes is increasing in absolute terms." However, she also notes the formidable challenges of developing an "empirically realizable model" not least because of the problems of common units of measurement for amounts of travel and of ICT use. Mokhtarian (2003) highlights the limitations of empirical evidence to be able to address causality between ICTs use and travel. Her examination of international evidence has led her to a con- 
clusion that (Mokhtarian 2003, 54) "We can say with confidence...that the empirical evidence for net complementarity [stimulation of travel] is substantial although not definitive, and the empirical evidence for net substitution appears to be virtually non-existent." Her later work continues to probe the challenge of net consequences for the motor age of the digital age (Mokhtarian 2009), questioning why we face the paradox of travel and congestion increasing in the face of an advancing digital age that offers the opportunity of alternative means of access.

A more recent review by Aguiléra et al. $(2012,664)$ notes that in terms of the question of whether ICTs stimulate or reduce travel demand, "[i]n spite of a large amount of empirical research, the answer is still fairly unclear." They conclude, according with much of Mokhtarian's thinking, that while the question may be legitimate, seeking to address it directly is probably futile. They suggest a need to more strongly acknowledge the gradual changes to our lifestyles resulting from the digital age and a need to focus attention on "how mobile ICTs are transforming many aspects of our daily lives and especially how they are helping to reshape the temporal and spatial organization of everyday activities" (Aguiléra et al. 2012, 667).

In other words, we are dealing with a complex socio-technical system in terms of the nexus of the motor and digital ages and to seek out definitive "truths" about net change is simply not possible. While Mokhtarian's paradox may have prevailed until recently, new empirical signals of a puzzling nature have arisen concerning the motor age: in a number of countries it seems the inexorable growth in car traffic has stopped, at least temporarily. This phenomenon has been labeled "peak car."

\section{$5 \quad$ Peak car}

In 2012 Goodwin observed that "[i]n many advanced economies, car use per head, and sometimes total car traffic, has shown low growth. In some countries (and especially cities) it has declined" (Goodwin 2012 , 4). This observation is not simply a reflection of the global economic recession-it refers to prerecession years concerning the new millennium. Goodwin is commonly credited with labeling this phenomenon "peak car." However the label can infer a determination of what is happening and what will be happening in future in terms of the motor age. This is not the intention and Goodwin (2012) summarizes (at least) three hypotheses for observed trends in recent data on car travel, which he labels "uninterrupted growth" (i.e., present figures reflect a blip in an otherwise upward growth trend); "saturation" (i.e., demand is at a plateau such that levels of car traffic have become more or less stable); and "peak car" (i.e., car use per head is peaking or has peaked and in turn is in decline (only countered at the aggregate by population growth)). These remain hypotheses because testing them rests upon post-recession data points running into the future.

\subsection{Multiple factors at work}

Two significant source of further insight into the phenomenon (and more sources continue to emerge, e.g., Lyons and Goodwin (2014)) are the special issue of Transport Reviews edited by Goodwin and Stokes (2013) which is devoted to peak car; and an analysis of national travel survey data for Great Britain for the period between 1995 and 2007 (Le Vine and Jones 2012). Both sources offer a richness of insight into the phenomenon which in sum highlights a series of (possible) contributory factors at work but also that "no single straightforward explanation" (LeVine and Jones 2012, xi) is apparent and "the driving factors for car use interact in a complex way" (Goodwin and Van Dender 2013, 252). Aggregate trends in travel mask significant underlying variations whereby both increases and decreases in car use can be observed.

Levels of per capita car use are found to be lower in dense urban areas than rural areas. In examining the peak car phenomenon in the UK, Headicar (2013) observes the increase in the last decade of the 
share of the total population living in more urbanized areas and in turn indicates that this has contributed to the observed overall reduction in per capita car use. Le Vine and Jones (2012) in their study also highlight the urban/rural distinction, observing of the data over a ten year period that car mileage per resident per year in London has gone down by $20 \%$ while for rural residents it has increased by $6 \%$.

A notable trend is that of fewer young people (especially males) acquiring driving licenses and correspondingly declines in per capita car use being observed. Delbosc and Currie (2013) seek causes for such decline by examination of observed decline in nine different countries. Potential causal factors are categorized as: life stage; affordability; location and transport; driver licensing regulations; and ecommunication. While causality is explored, results are inconclusive with the authors acknowledging (as others do) the need for much more work, especially regarding e-communications which is seen as still being an emerging area for investigation (as noted also, and not only applicable to younger people, by van der Waard et al. (2013)). Le Vine and Jones (2012) too acknowledge the possible contribution of ICTs to reduced car use; and van Wee (n.d.) hypothesizes that young people being less car oriented could be symptomatic of a transition towards greater emphasis on ICT-based activities.

Importantly in relation to this paper, Goodwin and Van Dender $(2013,250)$ observe that "the identification of a precise turning point at which the historic growth of car use slowed down, or came to a halt, is almost impossible...A transition can only be recognized in retrospect."

At this point in the paper we can observe that the challenges of attempting to understand, for some years, the net effect of the interaction of ICTs use and travel are in fact inter-twined with and confounded by now attempting to understand puzzling new trends in car use. These are especially poorly understood in relation to the effects of ICTs use and yet such use is held up as a candidate contributory factor. As such this might signal an important shift away from Mokhtarian's paradox of increasing ICTs use (previously) occurring in the face of unabated congestion.

Where then might we now turn to make some sense of this complexity and the accompanying compelling sense that something important is happening at the moment to the shape and scale of travel demand (concurrently with the digital revolution taking place)? This brings us to the paper's hypothesis. This is articulated in the next section through a socio-technical conceptualization of society known as the Multi-Layer Perspective.

\section{Regime transition}

Geels (2012) suggests of transport studies that it has been dominated by the thinking of neoclassical economists and of engineers. This echoes the same view by Schwanen et al. $(2011,1002)$ who go on to suggest that "most research is predicated on the use of quantitative methods embedded in positivist epistemological frameworks." Both observations point to a deficit of multi- and indeed inter-disciplinary thinking in understanding and responding to the complex socio-technical systems of both transport and wider society. Frank Geels has been a significant pioneer of a "heuristic framework" known as the MultiLayer Perspective (MLP) (Geels 2002, 2004; Geels et al. 2012) which responds to this by considering the "co-evolution and multi-dimensional interactions between industry, technology, markets, policy, culture and civil society" (Geels 2012, 471).

\subsection{The multi-layer perspective}

The MLP concerns three analytical levels: niches, the socio-technical regime and the socio-technical landscape. The landscape may be seen as the backdrop for the regime in which actors engage. It is seen to represent "the greatest degree of structuration in the sense of being beyond the control of individual actors" (Geels 2012, 473). Simply put, a regime encapsulates the way of the world as we know it and within 
which the various actors engage-it is an "alignment of existing technologies, regulations, user patterns, infrastructures, and cultural discourses" (Geels 2012, 473). Niches are innovations that can often fail to gain traction but which in some cases may become the beginnings of more substantial future change as they strengthen in salience and enjoy growing adoption levels. Such change can be absorbed into, and become adaptations to, the incumbent regime or may, ultimately and over time, bring about a transition from one regime to another. Regimes are often established and long lasting and tend to be preserved because of such factors as path-dependency, lock-ins and vested interests. However, history reveals that significant regime transitions do occur at different levels - but they take time. Geels (2001) highlights the examples of sailing ships to steam ships (between 1840 and 1890) and horse-and-carriages to cars (between 1880 and 1920).

In Geels' examination of whether there is a transition in society towards low-carbon transport (Geels 2012) he considers the "possible shift towards an information society" as one of three destabilizing landscape pressures for what he and colleagues (Geels et al. 2012) refer to as the automobility regime. It should be noted that he also considers the diffusion of ICTs into everyday life as a niche development. He goes on to suggest that "we are only in the early phases of a low-carbon transition in the transport domain” (Geels 2012, 479).

\subsection{From stability to destabilization of the automobility regime}

Through the MLP conceptualization, it is possible to articulate this paper's hypothesis, reflecting upon the earlier insights that have been drawn out.

The motor age can be recast as the automobility regime. This regime sees actors in government and industry especially, strongly influenced by the epistemological thinking that has bound the regime characterized by the car's contribution directly to prosperity through its industry of production, by its contribution to people's right to choice and by its contribution to the connectivity between people, goods, services and opportunities that underpins economic and social activity. Strong effects of path dependency, lock-in and vested interests serve to create inertia to any significant adaptation to the regime. A notable example of regime preservation was the government rescue in the US of Chrysler and General Motors as part of a global crisis between 2008 and 2010 also affecting European and Asian motor manufacturers.

Importantly, it might be suggested that interest in how the digital age can impact upon the motor age has inappropriately focused upon ICTs as niches and has then sought to understand cause and effect in terms of how strongly niches are developing and will develop and how they will influence the regime. To suggest "inappropriate" is explained as follows.

Attempting to examine the (localized) effects of specific niche ICT developments on the automobility regime neglects to acknowledge the more potent indirect and cumulative influence of people's growing use of, and dependency upon, ICTs in their everyday lives such that it begins to influence more fundamentally the competencies, expectations and norms of how we communicate, make decisions, co-create knowledge and transact in society. Thus, in agreement with Geels, the digital age is influencing the landscape layer of the MLP in a way that in turn begins to destabilize the regime. Countervailing forces within the regime may have been giving a strong semblance of the digital age and ICTs not having a noticeable effect. This will in part have been because it has been impossible to secure convincing empirical evidence as to the net effect of ICTs on travel, thus allowing the significance of the digital age from the automobility regime's perspective (especially within transport policy and the transport industry) to be denied or ignored. 


\subsection{In transition to a new regime}

My hypothesis is that we are in the midst of a regime transition for transport. While the digital age is characterized by a seemingly accelerated pace of change, this will be less so for the landscape layer than for the niches layer. Consequently it would not be unreasonable to assume that the transition has some way to go-perhaps decades-and will need more time before confidence grows that a new regime is indeed arising from transition. Yet the recent data on car use for a number of countries examined through the lens of "peak car" suggests the regime may indeed be showing significant signs of instability. It is also appropriate to note that the apparent close coupling of economic activity and traffic activity during the years of stability of the automobility regime (Figure 1), is now "decoupling." Traffic intensity is the amount of "input" of traffic (vehicle kilometres travelled) per unit "output" of economic activity (GDP). Between 1980 and 1992 in Great Britain, traffic intensity increased. However, since then (to 2008) it has reduced significantly_ "GDP has increased by 56 per cent compared with a rise in road traffic of 23 per cent" (DfT 2010,13). I would assert that the true coupling is between accessibility and economic activity, not between mobility and economic activity (see also Banister and Stead (2001)). Motorization has until more recently been the dominant manifestation of accessibility. The digital age has been presenting — at both landscape and niche levels_-powerful new opportunities for access without mobility.

\subsection{The regime of multimobilities}

How then might the emerging new regime be characterized? In very specific terms the answer is uncertain. It will depend (alongside a number of other social, technological, economic, environmental and political driving forces) upon how the path of technology development depicted in Table 1 continues to unfold over time and with what consequences for society and transport. However, I propose that we are moving into a new regime that will include the following features:

1. People will use forms of physical and virtual mobility much more interchangeably in order to access people, goods services and opportunities.

2. These "multimobilities" will enable individuals and organizations to be flexible and responsive to changing circumstances such as price signals or life events.

3. People will much more easily adjust their mobility split between physical and virtual (and between motorized and non-motorized mobility).

4. Distinctions between activity time and travel time will blur further and individuals will move seamlessly between physical, augmented reality and virtual encounters.

5. Workers in the knowledge economy of the regime will have an increasingly weak link between where they live and who they work for and with.

6. Car ownership will seem increasingly less important and car use will seem increasingly banal. Shared use of mobility resources will be favored. While use of cars (of whatever form of propulsion and whether or not autonomous) will continue, the car will be seen as a background technology serving a purely functional purpose.

\section{$7 \quad$ Responding to the transition}

The new regime (and the transition towards it) will call for government and industry actors in the transport sector to undergo significant epistemological adjustments.

The hypothesis itself is contestable and only in the fullness of time will it be shown to be supportable or not. However, I believe it to be a plausible outlook for the future. Others may argue that preservation of the incumbent regime of automobility (albeit with an ongoing evolution in its makeup) is also plausi- 
ble. Taken together, this underlines that the outlook for the future is uncertain and the extent of this uncertainty now seems more pronounced than in recent decades.

\subsection{Scenario planning}

In this context the suitability of forecasting the future must be brought into question - especially so if this is the principal tool used to inform policymaking and key investment decisions. Forecasting has a tendency to conceal uncertainty (Government of Queensland, 2000) even if this is not its express intention. It is predicated on certain assumptions about key underlying drivers of future states. Parameter values of such drivers can be changed but whether or not the drivers sufficiently explain future states is a separate matter.

I would concur with Goodwin and Van Dender (2013) that greater engagement with scenario planning is therefore called for to enable key actors to "rehearse the future" rather than have it thrust upon them and find themselves ill-equipped to engage sufficient socio-technical thinking to respond effectively. Scenario planning exposes uncertainty by allowing a wider set of drivers of change to be considered than may be embodied in forecasting. It involves a deliberative process of engagement of a number of actors and commentators whereby uncertainty is embraced with the development of divergent yet plausible depictions of the future. These depictions take the form of narrative scenarios of the future. While qualitative in nature, they can also have quantified features attributed to them if scenario planning is combined with modeling tools (e.g., Chatterjee and Gordon, 2006).

Scenario planning would readily enable the plausibility of this paper's hypothesis to be further explored with policymakers. However, scenario planning does not provide policymaking answers. It provides informed thinking and alternative perspectives on uncertainty so as to allow key policymaking questions to be more robustly examined.

\subsection{Opportunity and choice}

An important change of mindset is needed. Given the reduced ability to predict the future and in turn make transport policy decisions that support that future, there is a need instead to recognize that this creates an opportunity (if not a necessity) to make choices about the sort of future mobility and society that we wish to have, and use these to govern the policymaking and investment decisions needed to guide us towards that future. Governments may of course wish to avoid being (seen to be) too interventionist and instead allow the market to drive change and then support that change and/or take steps to ameliorate any adverse effects. In this context it remains important that policymaking and investment are robust against a range of different futures (Lyons and Goodwin, 2014).

\subsection{Research}

As David Levinson concluded at the end of the World Symposium on Land Use and Transport Research at which this paper was presented (Delft, 24-27 June 2014) "developing new plastic, adaptable and flexible designs for land use and transport systems, I believe, is the key research and policy question going forward." In relation to the hypothesized transition, allied to Professor Levinson's observation, the following research priorities seem appropriate in concluding this paper:

1. To draw more strongly on the fields of science and technology studies and political science to both examine transport and land use policymaking processes and politics and to engage with these processes in ways that introduce new epistemological perspectives and an openness to Levinson's key consideration above. 
2. To continue to apply "bottom-up" examination of specific ICT-related behaviors and their travel consequences since this will continue to inform how the niches layer in the MLP is evolving.

3. To give greater attention to examining-both quantitatively but especially qualitativelypeople's overall lifestyle attitudes and behaviors, including using life-course analysis techniques in order to better detect and understand deeper seated change commensurate with the landscape and regime layers in the MLP.

4. To examine, compare and contrast the experiences and views of digital natives and digital immigrants in relation to physical mobility, virtual accessibility and locational decisions for home, employment and leisure.

5. To seek out and examine "case study microcosms" of emergent regime change (either amongst particular social groups or particular geographic locations) to better inform wider examination of the plausibility of different future states for wider society and in turn different configurations of land use and transport systems.

6. To employ scenario planning to derive different plausible manifestations of a multimobilities regime and in turn apply a socio-technical lens to "imagineering" new or adapted designs for our land use and transport systems that would be compatible with such manifestations.

\section{Acknowledgements}

I would like to thank the two reviewers of this paper for their valuable feedback which has helped improve the final version. I would also like to thank the Organising Committee of the 2014 World Symposium on Transport and Land Use Research for the keynote invitation which provided the stimulus for preparing this paper. I would finally like to acknowledge the New Zealand Ministry of Transport. At the time of writing I am on part-time secondment to the Ministry as a Strategy Director with the task of addressing future demand for mobility in the face of uncertainty. This secondment and the issues it confronts have been symbiotic with the development of this paper.

\section{References}

Aguiléra, A., C. Guillot, and A. Rallet. 2012. Mobile ICTs and physical mobility: Review and research agenda. Transportation Research 46A: 664-672.

Andreev, P., I. Salomon, and N. Pliskin, 2010. Review: State of teleactivities. Transportation Research C 18: 3-20.

Banister, D. and D. Stead. 2002. Reducing transport intensity. European Journal of Transport and Infrastructure Research 2(3/4): 161-178.

Buchanan, C. 1963. Traffic in Towns. Ministry of Transport, HMSO, London.

Button, K. and R. Maggi. 1994. Videoconferencing and its implications for transport: An Anglo Swiss perspective. Transport Reviews 15(1): 59-75.

Chatterjee, K. and A. Gordon. 2006. Planning for an unpredictable future: Transport in Great Britain in 2030. Transport Policy 13, 254-264.

Davison, G. 2004. Car Wars: How the Car Won Our Hearts and Conquered Our Cities. Allen and Unwin.

Delbosc, A. and G. Currie. 2013. Causes of Youth Licensing Decline: A Synthesis of Evidence. Transport Reviews. 33(3)—Special Issue on Peak Car: 271-290.

DETR 1998. A New Deal for Transport—Better for Everyone. Transport White Paper, Department for Environment, Transport and the Regions, TSO, London. 
DETR 2000. Transport 2010-The ten year plan. Department of the Environment, Transport and the Regions, July, TSO.

DfT 2010. Transport Trends 2009 Edition. Department for Transport, London.

DfT 2013. Road Transport Forecasts 2013-Results from the Department for Transport's National

Transport Model. Department for Transport, London.

https://www.gov.uk/government/uploads/system/uploads/attachment_data/file/212474/roadtransport-forecasts-2013.pdf.

DoT 1989. Roads to Prosperity. White Paper on Transport Policy, Department of Transport, HMSO, London.

Dudley, G. 2014. The Motor Car and the Construction of a New World. Prepared for the New Zealand Ministry of Transport, July.

Felstead, A. 2012. Rapid change or slow evolution? Changing places of work and their consequences in the UK. Journal of Transport Geography 21: 31-38.

Geels, F. 2001. Technological transitions as evolutionary reconfiguration processes: A multi-level perspective and a case-study. Paper presented at Nelson and Winter Conference, June 12-15, Aalborg, Denmark. http://www.druid.dk/conferences/nw/paper1/geels.pdf.

Geels, F. 2002. Technological transitions as evolutionary reconfiguration processes: a multi-level perspective and a case-study. Research Policy 31(8-9): 1257-1274.

Geels, F. 2004. From sectoral systems of innovation to socio-technical systems: Insights about dynamics and change from sociology and institutional theory. Research Policy 33(6-7): 897-920.

Geels, F. 2012. A socio-technical analysis of low-carbon transitions: introducing the multi-level perspective into transport studies. Journal of Transport Geography 24: 471-482.

Geels, F., R. Kemp, G. Dudley, and G. Lyons (Eds.). 2012. Automobility in Transition? A SocioTechnical Analysis of Sustainable Transport. Routledge, New York.

Goodwin, P. 1995. Car Dependence. RAC Foundation for Motoring and the Environment, London.

Goodwin, P. 2012. Peak travel, peak car and the future of mobility: Evidence, unresolved issues, policy implications, and a research agenda. International Transport Forum round table on long run trends in travel demand. Paris, OECD.

http://www.internationaltransportforum.org/jtrc/DiscussionPapers/DP201213.pdf.

Goodwin, P. and K. Van Dender. 2013. Peak Car-Themes and Issues. Transport Review, 33(3) - Special Issue on Peak Car: 243-254.

Government of Queensland 2000. 4 Seeable Futures. Transport Portfolio Scenario-Based Planning for the Queensland Department of Transport and the Queensland Department of Main Roads 20002025.

Headicar, P. 2013. The changing spatial distribution of the population in England: Its nature and significance for Peak Car. Transport Reviews 33(3)—Special Issue on Peak Car: 310-324.

Hepworth, M. and K. Ducatel.1992. Transport in the Information Age-Wheels and Wires. Chapter 3: The Telecommunications-Transport Trade-off. Belhaven Press: 29-49.

HM Treasury 2008. The King Review of low-carbon cars Part II: recommendations for action. March, HMSO, London.

HM Treasury 2013. National Infrastructure Plan 2013. HM Treasury, December, London.

Hubers, C. and G. Lyons. 2013. Assessing future travel demand-a need to account for non-transport technologies? Foresight 15(3): 211-227.

IGD 2011. Online Grocery Retailing: Building Capability for a Digital Future. Institute of Grocery Distribution.

Kenyon, S. and G. Lyons. 2007. Introducing multitasking to the study of travel and ICT: Examining its extent and assessing its potential importance. Transportation Research 41(A): 161-175.

Kenyon, S., G. Lyons, and J. Rafferty, J. 2002. Transport and social exclusion: Investigating the possibility of promoting inclusion through virtual mobility. Journal of Transport Geography 10(3): 207-19. 
Kenyon, S., J. Rafferty, and G. Lyons. 2003. Social exclusion and transport: A role for virtual accessibility in the alleviation of mobility-related social exclusion? Journal of Social Policy 32(3): 317-38.

Kulash, W. 1996. The Third Motor Age. Places 10(2): 42_49.

Le Vine, S. and P. Jones. 2012. On the move: Making sense of car and train travel trends in Britain. RAC Foundation, London.

Lyons, G. 2002. INTERNET_-Investigating New Technology's Evolving Role, Nature and Effects for Transport. Transport Policy, 9: 335-346.

Lyons, G. and P. Goodwin. 2014. Grow, peak or plateau — the outlook for car travel. Reportof a roundtable discussion in London on 20 May 2014, New Zealand Ministry of Transport, July. http://eprints.uwe.ac.uk/23277/.

Lyons, G. and H. Haddad. 2008. Commute replacement and commute displacement: the rise of partday homeworking. Transportation Research Record: Journal of the Transportation Research Board 2082: 1-7. Transportation Research Board of the National Academies, Washington, D.C.

Lyons, G. and Urry, J. 2005. Travel time use in the information age. Transportation Research, 39(A): 257-276.

Mokhtarian, P. L. 1990. A typology of relationships between telecommunications and transportation. Transportation Research 24A (3): 231-242.

Mokhtarian, P. L. 2003. Telecommunications and Travel-The Case for Complementarity. Journal of Industrial Ecology 6(2)—E-commerce, the Internet and the Environment: 43-57.

Mokhtarian, P. L. 2009. If telecommunication is such a good substitute for travel, why does congestion continue to get worse? Transportation Letters 1: 1-17.

Mokhtarian, P. L. and I. Salomon. 2001. How derived is the demand for travel? Some conceptual and measurement considerations. Transportation Research 35A(8): 695-719.

Morton 1934. The Pageant of the Century. Odhams Press Ltd.

Norton, P. D. 2011. Fighting Traffic: The Dawn of the Motor Age in the American City. Cambridge, Mass: MIT Press.

ONS 2013. Internet Access_-Households and Individuals_2013. Statistical Bulletin. Office for National Statistics. http://www.ons.gov.uk/ons/dcp171778_322713.pdf.

Prensky, M. 2001. Digital Natives, Digital Immigrants. On the Horizon 9(5). MCB University Press. http://www.marcprensky.com/writing/Prensky\%20\%20Digital\%20Natives,\%20Digital\%20Immigrants\%20-\%20Part1.pdf.

Prensky, M. 2004. The Emerging Online Life of the Digital Native: What They Do Differently Because of Technology, and How They Do It. A work in progress. http://www.marcprensky.com/writing /Prensky-The_Emerging_Online_Life_of_the_Digital_Native-03.pdf.

Rogers, E. 1962. Diffusion of Innovations. New York: Free Press.

SACTRA 1994. Trunk Roads and the Generation of Traffic. Standing Advisory Committee on Trunk Road Assessment, HMSO, London.

SACTRA 1999. Transport and the Economy. Standing Advisory Committee on Trunk Road Assessment The Stationery Office, London.

Salomon, I. 1986. Telecommunications and travel relationships: a review. Transportation Research 20A (3): $223-238$.

Schwanen, T., D. Banister, and J. Anable. 2011. Scientific research about climate change mitigation in transport: a critical review. Transportation Research Part A 45(10): 993-1006.

SEU (2003). Making the Connections: Final Report on Transport and Social Exclusion. February, Social Exclusion Unit.

Van der Waard, J., P. Jorritsma, and B. Immers. 2013. New Drivers in Mobility; What Moves the Dutch in 2012? Transport Reviews 33(3)—Special Issue on Peak Car: 343-359.

van Wee, B. (conditionally accepted). Peak car: the first signs of a shift to ICT-based activities replacing travel? A discussion paper. Transport Policy. 